\title{
STANDARDIZED NURSING PLANS AND THEIR CLINICAL USE
}

\section{Monika Mankovecká ${ }^{1}$}

\begin{abstract}
This paper states the results of the study on the verification of the applicability of standardized nursing plans in clinical practice. The aim was to develop an effective model of managed nursing care for patients deficient in breathing. The research methods used were: a thought experiment, an experiment, a content analysis, and a survey. From the results, the author suggested four nursing plans which solve actual respiratory deficit. A basis for diagnosis was the classification system of nursing diagnoses NANDA. The plans were verified in two faculty hospitals at clinics of anaesthesiology and intensive medicine. Based on the standardized nursing plans, nursing care quality increased by $19 \%$. After analysis of the unmet criteria, the author found the most problematic criteria that were inconsistent with the standard. In the last part of the study, a survey of the nurses defined the advantages of standardized plans for nurses and patients.
\end{abstract}

UDC Classification: 614.2; DOI: http://dx.doi.org/10.12955/cbup.v6.1275

Keywords: Standardized nursing plans. Nursing care quality. Respiratory deficit.

\section{Introduction}

An organizational form of nursing care at departments of anaesthesiology and intensive medicine (hereinafter DAIM) differs from the forms at departments with standard care. Intensive nursing includes care for seriously ill people in life-threatening conditions. The nursing process as a systematic, rational method of providing nursing care has its specifics in each step at DAIM. Clinical practice showed that the biggest problem is the second step - diagnosis and the third step - planning. A nursing plan contains one or two diagnoses. And each nurse has "her universal" diagnosis that she uses in most patients. Based on long-term practical experience, we decided to develop standardized nursing plans.

\section{Standard nursing plans}

Standard nursing plans provide minimally acceptable standards of provided care, however, they do not provide individual care. They are based on the specific issue of the nursing process in a defined group of patients, or patients in the same situation in whom it is possible to expect certain responces to planned interventions (e.g.: patients in a critical condition, after a surgery). A plan specifies the most typical nursing diagnoses, goals, expected outcomes, and the most suitable interventions. The biggest priority for using standard plans is time saving. The fast pace of work in DAIM makes nurses assess and evaluate patients' conditions within minutes or seconds, and be able to react in an equally short time. Despite critical conditions, provided care needs to be maximally efficient and coordinated. Professional knowledge and skills and an ability to predict allow nurses, next to actual diagnoses, to deal with potential patient's problems too. Standardized nursing plans are used to help nurses in assessment, diagnosis and decision making when providing quality nursing care in conditions when a seriousness of a situation does not allow nurses to write a model nursing plan.

A nursing diagnosis process creates a framework to plan targeted care. To determine nursing diagnoses, we used the classification system NANDA-I from which we selected the diagnoses dealing with respiratory deficits. We chose respiration as the most basic - physiological need of living organisms because respiration failure results in cardiovascular system failure with a gradual failure of the whole organism. When dealing with the deficits in needs of people, respiratory deficit is the most serious problem that is necessary to be dealt with as a primary priority.

\section{Research}

The study was focused on diagnosis and planning of nursing care in patients in critical conditions at the departments of anaesthesiology and intensive medicine. After the literature review, we set the main study objective as: the development of an effective model of managed nursing care for patients using the classification system NANDA-International standardized nursing plans.

\section{Research hypotheses}

$\mathrm{H} 1$ : We assume that nursing care in the critically ill with respiratory deficits will be of a higher quality in the experimental group with the use of the standardized nursing plans than in the control group.

\footnotetext{
${ }^{1}$ Department of Clinical Disciplines and Urgent Medicine, Faculty of Social Sciences and Health Care, Constantine the Philosopher University in Nitra, Romania, mmankovecka@ukf.sk
} 
$\mathrm{H} 2$ : We assume that during the verification of the standardized nursing plans in clinical practice we will find deficiencies and differences between the practice and the standard that will be conditioned by care management traditions in the individual clinics.

H3: We assume that the nurses who conducted the experiment will express their agreement with the developed standardized nursing plans and their significance for clinical practice.

\section{Study methodology}

We conducted a collection of empirical data from clinical practice in the selected healthcare facilities with their written consent.

1 Faculty Hospital in Nitra (hereinafter FH Nitra): Clinic of Anaesthesiology and Intensive Medicine

2 Faculty Hospital in Trnava (hereinafter FH Trnava): Clinic of Anaesthesiology and Intensive Medicine

\section{Sampling}

We divided the sample into two groups. The first group included the respondents hospitalized at the clinics of anaesthesiology and intensive medicine in both faculty hospitals who were divided into the experimental and control group. The main research group included patients in critical condition who had respiratory deficit. In the experimental group, the patients were provided with nursing care in accordance with the developed standardized nursing plans. The plans were verified in 100 patients, consisting of 50 patients from the FH Nitra and 50 patients from the FH Trnava. In the control group, the patients were provided with the established routine nursing care. We evaluated this care again in 100 patients, including 50 patients from the FH Nitra and 50 patients from the FH Trnava.

The second sample consisted of nurses who provide nursing care at the departments of anaesthesiology and intensive medicine in the selected healthcare facilities. There were 29 nurses participating in the study, including 17 nurses in the FH Nitra and 12 nurses in the FH Trnava. We divided the nurses into two groups - experimental and control. The experimental group included the nurses who were willing to participate in the study. The remaining other nurses were in the control group.

The experimental group in the FH Nitra included ten nurses and the experimental group in the FH Trnava was represented by six nurses. In each subgroup of the experimental group, one nurse was appointed a study coordinator purposefully chosen by the type of education (minimally the first university level $\mathrm{Bc}$.). The nurses in the experimental group were methodologically trained in using the standardized nursing plans separately so that we did not influence the study results in the nurses working in the control group.

To maintain the continuity of care, the nurses were asked to change their shifts within the same group, either the experimental one or the control one.

\section{Research plan}

In the first step, we selected the diagnoses from NANDA-International 2009-2011 that are useable in the diagnosis of needs in patients hospitalized at DAIM. In the second step, we selected the diagnoses that are useable in critically ill patients to provide quality nursing care. From the diagnoses, we selected those that deal with respiratory deficit, because respiration is a basic vital function.

\section{Research methods}

1 A thought experiment was used for the development of the standardized nursing plans.

2 An experiment was conducted in which we induce a change in one or more variables by a purposefully induced phenomenon. This was chosen as the main research method. We achieved the manipulation with the provided nursing care through an implementation of the developed standardized nursing plans.

3 A content analysis was conducted as a quantitative data analysis that focused on the medical records for the ICU and AIM settings. The medical records and audit forms were used to obtain the relevant data related to the quality of provided nursing care in the experimental and control groups.

4 A survey for nurses was conducted in the experimental sample to determine their opinions on the implementation of standardized nursing plans in clinical practice. The questionnaire consists of four open-ended items. 


\section{Standardized nursing plan development}

We developed the standardized nursing plans gradually, in individual steps. The basis for our plans was the classification system of nursing diagnoses NANDA-International 2009-2011. First, we chose a problem - respiratory deficit - we wanted to resolve. Then, we selected from the list all actual diagnoses that deal with respiratory deficits. We chose four adequate diagnoses: 00030 Impaired gas exchange, 00031 Ineffective airway clearance, 00032 Ineffective breathing pattern, and 00033 Impaired spontaneous ventilation. In the next step, we developed checklists and attached them to the standard. The audit contains evaluation methods and checklist criteria related to the individual criteria of the structure, process and outcome.

\section{Interpretation and discussion}

A nursing process, as a tool on modern nursing, is a systematic and logic method of providing nursing care. In the present period of limited financial resources it is necessary to manage the provision of nursing care also from the perspective of economics. Treatment of the critically ill is demanding both from the medical and economic aspects. A model of managed care introduces the philosophy, attitudes, effective use of resources, and personal responsibility for the provided care. Also, managed care means implementation of innovations and tools by nurses to increase the quality of the provided care (Škrloví, 2003). Standards make a nursing process more effective through the development of standardized nursing care plans (Farkašová, Kubicová, 2009). Standards fit in a wider process of care quality management (Kováčiková, 2008). We can elaborate processual standards as standards of nursing methods for procedures and as standards of nursing interventions in a nursing process that can be focused on individual nursing diagnoses or a result from a disease (Holmanová, Žiaková, 2003). We can define a nursing audit as a quality measurement used to find differences between reality and the standard (Pátá, 2006).

In the first hypothesis (H1), we assumed that nursing care in the critically ill with respiratory deficits would be of a higher quality in the experimental group with the use of the standardized nursing plans than in the control group.

Through the research we found that the nursing care quality in the experimental group in which the nurses worked in accordance with the developed standardized plans increased in comparison with the nursing care quality in the control group in which the nurses worked by the established methods.

\begin{tabular}{|c|c|c|c|c|c|c|}
\hline \multirow{2}{*}{$\begin{array}{l}\text { Nursing } \\
\text { diagnosis }\end{array}$} & \multicolumn{2}{|c|}{ FH Nitra } & \multicolumn{2}{|c|}{ FH Trnava } & \multicolumn{2}{|c|}{ Total } \\
\hline & $\begin{array}{c}\text { Experimental } \\
\text { group }\end{array}$ & $\begin{array}{c}\text { Control } \\
\text { group }\end{array}$ & $\begin{array}{c}\text { Experimental } \\
\text { group }\end{array}$ & $\begin{array}{c}\text { Control } \\
\text { group }\end{array}$ & $\begin{array}{l}\text { Exper. } \\
\text { group }\end{array}$ & $\begin{array}{c}\text { Control } \\
\text { group }\end{array}$ \\
\hline 00030 & $96 \%$ & $82 \%$ & $94 \%$ & $86 \%$ & $95 \%$ & $84 \%$ \\
\hline 00031 & $91 \%$ & $66 \%$ & $95 \%$ & $70 \%$ & $93 \%$ & $68 \%$ \\
\hline 00032 & $95 \%$ & $75 \%$ & $94 \%$ & $74 \%$ & $95 \%$ & $75 \%$ \\
\hline 00033 & $94 \%$ & $75 \%$ & $93 \%$ & $73 \%$ & $94 \%$ & $74 \%$ \\
\hline Total & $94 \%$ & $75 \%$ & $94 \%$ & $76 \%$ & $94 \%$ & $75 \%$ \\
\hline
\end{tabular}

Analyzing the calculated data, we can state that an average value of the nursing care quality in the $\mathrm{FH}$ Nitra in the control group was $75 \%$ and in the experimental group it was $94 \%$. The nursing care quality with the use of the standardized nursing plans increased by $19 \%$. In the FH Trnava, an average value of the nursing care quality in the control group was $76 \%$ and in the experimental group it was $94 \%$. The nursing care quality increased by $\mathbf{1 8} \%$ with the use of the standardized plans. After evaluation and averaging the measured values, the nursing care quality in the experimental group was $94 \%$ and in the control group it was $75 \%$. Using the standardized nursing plans, the nursing care quality increased by $19 \%$.

On the basis of the achieved results, we can state that the hypothesis $\mathbf{1}(\mathrm{H} 1)$, in which we assumed that nursing care in the critically ill with respiratory deficits would be of a higher quality in the experimental group with the use of the standardized nursing plans than in the control group, was not disproven. 


\section{H2 verification}

Despite a sufficient scientific base and university education in nursing, the biomedical model of nursing care, which was traditional before 1994 - before adopting the Nursing Concept, is still dominant and priority in nursing practice as well. Usage of the individual steps of the nursing process in nursing, particularly diagnosis and intervention planning, is conditioned by perceptions of own limited interventions. Another limiting factor is diagnosis and solving of universal deficits, always the same problems related to the medical diagnoses (Holmanová, Žiaková, Čáp, 2009). When developing nursing plans, we used professional medical and nursing local and foreign literature. We defined the process criteria in accordance with the latest scientific knowledge from intensive medicine and care, and we also used our long-term work experiences in DAIM. We set the minimal standard achievability level at 93 $\%$ because of innovativeness of the idea/topic and the biomedical approach towards nursing practice. We assumed there must be differences in the provision of nursing care in the healthcare facilities as a result of specifics of nursing care management of the individual departments.

In the second hypothesis (H2), we assumed that during the verification of the standardized nursing plans in clinical practice we would find deficiencies and differences between the practice and the standard that would be conditioned by management traditions in the individual clinics.

Through the research we found that in the verification of the standardized nursing plans in clinical practice, the criteria that were not met in accordance with the standard were found. Even despite the introduced standard, some nurses were not able to accept and implement them. The reason for ignoring some process criteria were that they still used former norms of nursing practice, The nurses had fear of to enforce their legal competences, and the subordinate relationship to doctors.

\begin{tabular}{|c|c|c|c|c|}
\hline \multicolumn{3}{|c|}{ Table 2: Unmet criteria } & \multicolumn{2}{c|}{ FH Trnava } \\
\hline & \multicolumn{2}{|c|}{ FH Nitra } & Criterion & \% \\
\hline Diagnosis code & Criterion & \% & P4 & $47 \%$ \\
\hline \hline $\mathbf{0 0 0 3 0}$ & P4 & $40 \%$ & P3A & $100 \%$ \\
\hline $\mathbf{0 0 0 3 1}$ & P7B & $83.3 \%$ & P4 & $50 \%$ \\
\hline $\mathbf{0 0 0 3 2}$ & P24 & $100 \%$ & P26 & $100 \%$ \\
\hline $\mathbf{0 0 0 3 3}$ & P26 & $64 \%$ & \multicolumn{4}{l}{} \\
\hline Source: Authors
\end{tabular}

After analysis of the obtained results, we can state that despite the developed standardized plans, not all the criteria were met in the provision of nursing care of the patients with respiratory deficits. The most problematic criteria in the individual diagnoses were the criteria related to auscultation of breath sounds. In the FH Nitra, the polemical criteria were: ventilation of patient during pulmonary hygiene by $100 \%$ oxygen, and a failure to provide rehabilitation care to patients with respiratory deficit. The presented deficiencies were argued as an incompetence of the nurses and as a tradition of methods at the department. After statistical analysis of the unmet criteria in the individual healthcare facilities, we found the deficiencies and differences between the practice and the standard. The nurses justified the failure to meet these criteria by stating that this procedure is not in their competence.

The extent of nursing practice is defined in the Regulation of the Ministry of Health of the Slovak Republic No. 470/2006 Coll. which specifies the extent of nursing practice provided by a nurse independently and in cooperation with a doctor and the extent of midwifery practice provided by a midwife independently and in cooperation with a doctor. In the category of independently provided nursing care, there are defined procedures according to which a nurse identifies the need of nursing care in an individual. A registered nurse measures, monitors and interprets the found numeric values and clinical data of physiological functions and vital functions in the extent necessary to provide nursing care (Sekáčová, 2009). After the analysis of the available resources, there is no support for a statement on a breach of competences either; thus, auscultation of breathing is fully in the competence of nurses. The American authors Ackley and Ladwig (2008) suggested nursing interventions in the nursing diagnosis 00030 of impaired gas exchange. They suggested auscultation of breath sounds every 1 to 2 hours. In the nursing diagnosis 00031 Ineffective airway clearance, Ackley and Ladwig (2008) recommended auscultation of breath sounds. Auscultation of breath sounds in the intervals of 1 to 4 hours was stated also by Lepiešová (2009), and Kozier, Erb, Olivier (1995). 
Based on the achieved data, we can state that the hypothesis $2(\mathrm{H} 2)$, in which we assumed that during the verification of the standardized nursing plans in clinical practice we would find deficiencies and differences between the practice and the standard that would be conditioned by management traditions in the individual clinics, was not disproven.

\section{H3 verification}

Considering the used biomedical model of providing nursing care in most healthcare facilities, and a lack of nurses working shifts, and the distrust to a change of nurses, we wanted to know the opinions of the nurses from the experimental group on the introduced plans. In the beginning of the cooperation, we found the distrust of nurses to the developed plans and participation in the experiment. Enforcing new facts and implementing a change, we accepted scepticism as a normal reaction. The nurses-coordinators and department management helped us overcome the initial scepticism. With respect to the atmosphere at the beginning of the cooperation, we wanted to know the opinions of the nurses from the experimental group on the introduced plans and their use in clinical practice after the experiment.

In the third hypothesis (H3), we assumed that the nurses who conducted the experiment would express their agreement with the developed standardized nursing plans and their significance for clinical practice.

Through the research we found that the nurses who conducted the experiment expressed their agreement with the developed standardized nursing plans and their significance for clinical practice

\begin{tabular}{|c|c|c|}
\hline \multicolumn{2}{|c|}{ Table 3: Evaluation of standardized plans by nurses from experimental group } \\
\hline Question & Positive evaluation & Critical evaluation \\
\hline Question 1 & $75 \%$ & $25 \%$ \\
\hline Question 2 & $100 \%$ & $0 \%$ \\
\hline Question 3 & $100 \%$ & $0 \%$ \\
\hline Question 4 & $93.75 \%$ & $6.25 \%$ \\
\hline Total & $\mathbf{9 2 . 2 \%}$ & $\mathbf{7 . 8 \%}$ \\
\hline Source: Authors & \multicolumn{2}{|}{} \\
\hline
\end{tabular}

To obtain the nurses' attitudes and opinions, we prepared four open-ended survey questions. From the first question we determined the opinions of the nurses on the developed plans. From the second question we pursued what significance the nurses ascribed to the standardized nursing plans for clinical practice. In the third question, we asked the nurses to define the main contribution of the standardized nursing plans. In the fourth question, we wanted to find out the nurses' opinions on the main contribution of the standardized nursing plans for patients.

After analysis of the determined facts, we can state that the nurses who participated in the experiment evaluated the presented standardized plans as beneficial for clinical practice. The nurses evaluated the standardized plans as defining the uniformed and correct method in providing nursing care. For nurses, the plans are manuals with precisely defined interventions listed in a time line and are used as legal protection of nurses. For patients, they provide confidence that the care they got was of high quality and was safe.

Based on the achieved results, we can state that the hypothesis 3 (H3), in which we assumed that the nurses who conducted the experiment would express their agreement with the developed standardized nursing plans and their significance for clinical practice, was not disproven.

\section{Recommendations for nursing practice and research}

The presented findings provide an alternative vision for development of intensive care for the future. The developed standardized nursing plans can be a basis for clinical practice and applied research in nursing. In conclusion, the presence of tasks that could be further elaborated and solved was demonstrated. We might divide the levels of solutions into three categories: the need of changes in the legislative, research levels in clinical practice, and nursing education.

$>$ To integrate legislatively the nursing practice in Slovakia with the international legislation through the abolishment of the Regulation of the Ministry of Health of the Slovak Republic No. 306/2005 Coll. which specifies the list of nursing diagnoses, and through enactment of the classification system of nursing diagnoses of NANDA-International.

$>$ To develop standardized nursing plans for all diagnoses and verify them in clinical practice. 
To develop a terminological dictionary for intensive care.

$>$ To prepare a process of national validation of the classification system of nursing diagnoses NANDA-I in Slovakia in cooperation with Czech professionals.

$>$ In the process of further nursing education, to include the issue of standardized nursing plans in the content of specialty training as educational material.

\section{Conclusion}

Achievement and maintenance of care standards requires from nurses' new abilities that were not used in the past. In the present, educated nurses should maintain and enhance their professional mastery and continuously develop a base of their professional knowledge. In the present, nurses must put the greatest emphasis on independence in decision making in their profession.

\section{References}

Ackley, B. J., Ladwig G. B. 2008. Nursing Diagnosis Handbook: An Evidence - Based Guide to Planning Care. 8th Edition, Missouri : Mosby, Inc., 2008. 937 p. ISBN 978-0-323-05192-7.

Bačišinová J., Valdmanová K. 2010. Faktory tvorby plánov ošetrovatel'skej starostlivosti a ich multidimenzionálnost'. [online]. Katedra ošetrovatel'stva, FZ PU v Prešove 2010. [Citované 11.03.2010]. Dostupné na internete: http://www.unipo.sk/7605

Farkašová, D., Kubicová, L'. 2009. Kvalita a štandardizácia ošetrovatel’skej starostlivosti. In: Farkašová, D. a kol. Ošetrovatel'stvo - teória. 2. vyd. Martin : Osveta, 2009, ISBN 978-80-80633-22-6, s. 191 - 206.

Holmanová, E., Žiaková, K. 2003. Význam štandardizácie ošetrovatel’skej starostlivosti. In Sestra, ISSN 1335-9444, 2003, roč. 2 , č. 2 , s. $6-8$.

Holmanová, E., Žiaková, K. - ČÁP, J. 2009. Reflexia aplikácie ošetrovatel’ských diagnóz vo výskume. In Čáp, J., Žiáková, K. (ed.). Teória, výskum a vzdelávanie v ošetrovatel'stve a v pôrodnej asistencii. Univerzita Komenského v Bratislave, Jesseniova lekárska fakulta v Martine. Ústav ošetrovatel'stva. Martin. 2009. ISBN 978-80-88866-61-9, s. 51-57.

Kapounová, G. 2007. Ošetřovatelství v intenzivnej péči. 1. vyd. Praha : Grada, 2007. 350 s. ISBN 978-80-247-1830-9.

Kovácsová, M. 2007. Komunikácia s onkologicky kritickým chorým na OAIM. In Ošetrovatel’ský obzor. ISNN 1336-5606, 2009 , roč. 4, č. 3 , s. 58 - 61 .

Kozierová, B. a kol. 1995. Ošetrovatel'stvo I, II. 1. slov. vyd. Martin: Osveta, 1995. 1474 s. ISBN 80217-0528-0

Lepiešová, M. 2009. Neefektívne čistenie dýchacích ciest. In: Gurková, E., Žiaková, K., Čáp, J. a kol. Vybrané ošetrovatel'ské diagnózy v klinickej praxi. Martin : Osveta. 2009. ISBN 978-80-8063-308-0, s. 199 - 206.

Pátá, M. 2006. Audit v ošetřovatelské praxi. In Archalousová, A., Kutnohorská, J. (ed.). „, Od Florence Nightingelové k současnosti aneb ošetřovatelství s novou tváří. "I. Mostecké dny sester. 4. - 5. 5. 2006 Sborník prednášek. Most : Tiskárna K\&B, s.r.o., 2006, ISBN 80-239-6603-0, s.36 - 38.

Škrloví, P. a M. 2003. Kreativní ošetřovatelský manažment. Praha : Advent-Orion s.r.o., 2003, 475 s. ISBN 80-7172-841-1. Sekáčová, M. 2009. Kompetencie sestry. [online]. 2009, [citované 2011-08-01]. Dostupné na: <http://www.sksapa.sk/20091120269/Aktuality-a-oznamy/kompetencie-sestry>. 